\title{
ANALYSIS OF THE ROLE OF COMMUNITY IN THE DEVELOPMENT OF IRRIGATION NETWORKS IN LUWU TIMUR DISTRICT, INDONESIA
}

\author{
Muharif $^{1 \star}$, Hakim A. ${ }^{2}$, Afandi A. ${ }^{3}$, Tamsil A. ${ }^{4}$ \\ ${ }^{1}$ Doctoral student, Environmental Science Program, Postgraduate School, \\ University of Brawijaya, Indonesia \\ ${ }^{2}$ Department of Public Administrative Science, Faculty of Administrative Science, \\ University of Brawijaya, Indonesia \\ ${ }^{3}$ Department of Agriculture, Faculty of Agriculture, University of Brawijaya, Indonesia \\ ${ }^{4}$ Faculty of Fisheries and Marine Sciences, Makassar Moslem University of Indonesia, \\ Indonesia \\ *E-mail: jurnal.ppsub@gmail.com
}

\begin{abstract}
National Food Security is one of the main objectives of agricultural development carried out by the government through increasing food production in both irrigated and rainfed land.Until now, there are still fundamental problems to achieve national food security, namely the availability of water resources and infrastructure for channeling irrigation water, while food needs are increasing.This condition causes various conflicts in the utilization of water resources. The control of this conflict requires handling in the form of the development of irrigation networks and improving the ability of human resources and management of water resources in a sustainable and equitable manner.Government policy in development is urgently needed to support the sector, including the management of irrigation systems at the farm level.Problem statement; The influence of participation, character, culture, and policy on the development of irrigation networks in Luwu Timur District.This research aims to analyze the factors of participation, character, culture, and policy towards the development of irrigation networks in Luwu Timur District. The method used to conduct this research is the statistical approach, Structural Equation Modeling-Amos (SEM-AMOS). The results of the analysis obtained that variable 1).Community participation has little role in developing irrigation networks in Luwu Timur District 2). Community characteristics play a role in the development of irrigation networks in Luwu Timur District.3) Community culture has little role in the development of irrigation networks in Luwu Timur District and 4) Policies play a role in the development of irrigation networks in Luwu Timur District.
\end{abstract}

\section{KEY WORDS}

Participation, character, culture, policy.

National Food Security is one of the main objectives of agricultural development carried out by the government through increasing food production in both irrigated and rainfed land. Until today, there are still fundamental problems to achieve it, namely the availability of water resources and infrastructure for channeling irrigation water, while food needs are increasing.This condition causes various conflicts in the utilization of water resources.Control of this conflict requires handling in the form of the development of irrigation networks and improving the ability of human resources as well as management of water resources in a sustainable and equitable manner.

Irrigation is an important component of agricultural development in Indonesia, which is mostly in rural areas.Indonesia is a country where most of the population lives from agriculture with rice as its staple food.Government policy in development is urgently needed to support the sector, including the management of irrigation systems at the farm level.

Furthermore, there are many government policies that regulate water and irrigation resources in Indonesia, including those stipulated in two legal grounds, namely Law No. 7 of 2004 concerning water resources and government regulation number 20 of 2006 concerning irrigation. 
But in reality, there are still many unclear things about the locus of the practice which must follow the rules of hydrological theory and in accordance with government structures which consist of macro-units on a regional basis (Kodoatie, and Sjarief, 2005).

Every construction development and irrigation management in each region must involve the participation of the surrounding community, especially the farmers.Farmers participation in the development and management of the irrigation system is stated in the Regulation of the Government of the Republic of Indonesia number 20 of 2006 concerning irrigation.Article 26 of the regulation mentioned that the farmers' participation in irrigation development and management can be realized in initial thinking, decision making, and the implementation of activities in development, upgrading, operation, maintenance, and rehabilitation.Farmers' participation can be realized in the form of donations of ideas, ideas, time, energy, material, and funds.This participation is also carried out individually or through water-use farmer associations based on the willingness and ability of the farming community as well as the spirit of partnership and independence and can be channeled through waterusing farmer associations in their working area.

But in reality, the community has not been much involved in the development and management of irrigation in several regions in Indonesia.One of them is in Luwu Timur District which is a research study area.The construction of irrigation networks in Luwu Timur District has not involved the community in its management.Meanwhile, based on Law Number 20 of 2006 concerning irrigation, community participation in development and management of irrigation is very necessary so that development can be in accordance with the needs of the community and it can also be involved in the operation, maintenance and rehabilitation of irrigation networks. The absence of community involvement in the management of this irrigation network has caused them not to have empathy for the management of irrigation networks.

The community does not have space to participate in the operation, maintenance, and rehabilitation of irrigation networks because the community does not have adequate institutions for the community to manage irrigation networks. Whereas in Article 27, Law No. 20 of 2006 concerning irrigation states that the government, provincial government, or district/city government in accordance with their authority should encourage the participation of farmers in the development of irrigation system management to increase their sense of belonging and responsibility for the sustainability of the system. The conditions that occur in Luwu Timur District are a problematic policy that is different from the policies in Government Regulation No. 20 of 2006 concerning irrigation.Therefore, this research needs to be done to determine the strategy of managing irrigation networks based on community participation with the support of local government.

\section{LITERATURE REVIEW}

Definition of analysis in the Contemporary Great Dictionary of the Indonesian Language written by Peter Salim and Yenni Salim (2002), describes the analytical understanding as follows:"Analysis is a problem-solving process begins with the existence of hypotheses or perceptions/presuppositions until it is proven true through some certainty, including experiments and others.Furthermore, etymologically, the word of analysis, according to the Great Dictionary of the Indonesian Language is, "the breakdown of various parts and the study of the part itself, as well as the relationship between the parts to get the right understanding and the whole meaning."

According to Harahap, (2004) the notion of analysis is "solving or uniting something into the smallest unit."

Analysis is the decomposition of a subject over various parts and the study of the part itself and the relationship between the parts to obtain the right understanding and the overall meaning.

Whereas according to M. Kasiram, (2006), data is sourced from the results of data collection, if the collected data is not analyzed, it will be meaningless goods, dead data, soundless data. Therefore, data analysis here serves to give meaning, meaning, and value 
contained in the data itself.Furthermore, Komaruddin (1991) states that analysis is an activity of thinking in order to describe a whole as a component so that the signs of components can be known, which are related to each other and functions in an integrated whole.

According to Kozier Barbara, a role is defined as a set of behaviors expected by others towards someone according to their position in a system. The role is influenced by internal and external social conditions and is stable.Therefore, the role is a form of behavior expected of a person in certain social situations.

According to Horton and Hunt (1993), the role is behavior expected of someone who has a status or position.For that reason, the various roles that are incorporated and connected to one status are called role sets, Merton (1968).

If the role is the behavior expected by someone at a certain status, then the role behavior is the actual behavior of the person who performs that role. Meanwhile, according to Abu Ahmadi (1982), the role behavior may be different from expected behavior due to several factors, thus defining a role as a complex to human expectations of the way individuals behave and act in certain situations based on their social status and function.

Community in English is a society derived from the word "socius" which means (friend).The term community is derived from the Arabic word "syarakayang" which means (participation). Community is a group of people who interact with each other. Society is possible to have infrastructure through the people who can interact with each other.Another definition, community is the unity of human life that interacts according to a certain system of customs that is continuous, and which is bound by a sense of shared identity. Continuity is a community unit that has four characteristics, namely:1) Interaction between citizens, 2).Customs, 3) Continuity of time, 4) A sense of strong identity that binds all citizens (Koentjaraningrat, 2009: 115-118).

The farming community, in general, is often understood as a uniform and general social category. That is, it is often not realized that there are differences in various aspects contained in this farming community.For example, differentiation in the farming community will be seen based on differences in the level of development of the community, the types of plants they plant, the technology or tools they use, the farming systems they use, topography or other physical-geographic conditions. Generally, the differentiative features of the farming community are the difference between unpretentious farmers, who are also often called traditional farmers (including farmers or agricultural entrepreneurs).

According to the Regulation of Minister of Public Works No.32/PRT/M/2007, irrigation networks are complementary channels, buildings, and buildings which are a unit that is needed for the provision, distribution, allocation, use and disposal of irrigation water.There are several types of irrigation networks, namely:

- Primary irrigation network is part of irrigated network consisting of the main building, main / main canal, its drainage, building for tapping, tapping buildings, and complementary buildings;

- Secondary irrigation network is part of an irrigation network consisting of secondary canals, sewers, buildings for tapping, tapping buildings, and complementary buildings;

- Tertiary irrigation network is an irrigation network functions as an irrigation water service infrastructure in a separate plot consisting of tertiary canals, quarter channels and waster channels, tertiary boxes, quarter boxes, and complementary buildings.

Irrigation networks are channels, buildings, and its complementary is unity needed for the provision, distribution, allocation, use and disposal of irrigation water. Irrigation channels are infrastructure that distributes water originating from Dam/Embung (retention basin) to agricultural land owned by the community. With this irrigation channel, the need for water for the farmers' fields will be guaranteed.

A lot of definition of participation have been expressed by experts, but in essence, they have the same meaning.Participation comes from English the word "participate" which means to take part (Willie Wijaya, 2004: 208). Whereas Fasli Djalal and Dedi Supriadi (2001: 201-202) define participation as an action made by decision makers to suggest groups or communities to be involved in the activity of submitting suggestions and opinions, goods, 
skills, materials and services. Participation also means that groups recognize their own problems, examine their choices, make decisions, and solve their problems.

According to Soegarda Poerbakawatja participation is:A symptom of democracy where people are included in the planning and implementation of everything centered on interests and also takes responsibility in accordance with the level of maturity and level of obligations (Soegarda Poerbakawatja, 1981: 251)

The definition of participation is always associated or synonymous with participation, so it can be said that participation is not based on physical fitness in the work but involves one's involvement so that it will lead to greater responsibility and donations (Darmawi, 2014)

According to H.A.R. Tilaar (2009: 287), participation is a manifestation of the desire to develop democracy through a decentralization process which is sought, among others, the need for button-up by involving the community in the planning and development process of the community.

Participation of community members is their involvement in the development, including activities in the planning and implementation of development programs undertaken by the surrounding community (Adisasmita 2006).Ndraha (1982) referring to Cohen (1977) states that there is no satisfactory definition of the term participation, therefore they limit it to development participation meaning the participation (active) of the community in the field of rural development.

Nasdian (2014) explains that participation supports the community to be aware of the situation and problems it faces as well as try to find solutions that can be used to overcome their problems (having critical awareness)

The implementation of development covering all aspects of new life will succeed if it is an activity involving all members of the community. This is explicitly stated by Tjokroamidjodjo (1974) quoted by Supriyadi (2010) that participation is important for development and even becomes one of the goals of development itself. as follows:

Cohen and Uphoff, (1977) in Girsang (2011) divided participation into several stages,

- A decision-making stage is realized through community participation in meetings. The intended decision-making phase is planning activities;

- The implementation phase is the most important stage in development because the core of development is the implementation. The real manifestation of participation is classified into three, namely participation in the form of thought and material contributions, as well as being the member;

- The stage of enjoying the results, matters used as an indicator of the success of community participation is in the planning and implementation stages. In addition, by looking at the position of the community as the subject of development so the greater the benefits of the program felt, the more possibility to achieve the target;

- The Evaluation Phase is considered important because community participation is feedback that can provide input to improve the implementation of the next program.

Character means a person's nature or personality.Coon (Zubaedi, 2011: 8) defines character as a subjective assessment of one's personality related to personality attributes that can or cannot be accepted by society. Character is the whole natural and disposition that has been mastered stably defining an individual in the overall order of psychical behavior that differentiates the way of thinking and acting.

The word character comes from the Latin word "kharakter", "kharassein", "Kharax", and the Greek words "Character", from charassein which means to make sharp. 25

According to the Indonesian general dictionary26, a character is interpreted as behavior; personality; psychological, moral or character traits that distinguish a person from others. While in the sociology dictionary27, a character is defined as a special feature of the basic structure of a person's personality (character; personality).

Griek, as quoted by Zubaedi argues that character can be defined as a guide to all permanent human characteristics so that it becomes a special sign to distinguish one person from another. 
Suyanto and Masnur Muslich stated that character is an individual's way of thinking and behaving which become the specialty of each individual to live and cooperate, both in family, society, and country.

Based on some of the meanings above, it can be interpreted that character is a person's specialty in behaving that distinguishes himself from others. Definition of character, personality, and individuality is indeed often confused in its use. This is because the term has similarities, namely something original in an individual who tends to settle permanently.

There are several cultural meanings according to some experts, one of whom is a wellknown Indonesian figure, Koentjaraningrat.According to Koentjaraningrat (2000: 181) cultural with culture as the basic words comes from sansakerta language "buddhayah", which is the plural form of buddhi that means "mind" or "reason".Therefore, Koentjaraningrat defines culture as "mind power" in the form of creativity, intention, and taste, while cultural is the result of creativity, intention, and taste.

Koentjaraningrat explained that basically there are many distinguish between culture and cultural, where culture is a pluralistic development of cultivation, which means the power of the mind.In Anthropology studies, culture is considered to be an abbreviation of cultural that has no difference from the definitions.For that matter, according to Koentjaraningrat, cultural is a whole system of ideas, actions and human works used as human property by learning.

For more details, Koentjaraningrat distinguishes three forms of culture, namely:(1) The manifestation of cultural as a complex of ideas, values, norms, regulations and so on.(2) The manifestation of cultural as a complex of activities and actions patterned from humans in a society.(3) The manifestation of cultural as objects produced by humans.

According to Liliweri (2003: 8) cultural is the view of life of a group of people in the form of behaviors, beliefs, values, and symbols that they receive unconsciously all of which are inherited through the communication process from one generation to the next.

Furthermore, Taylor, as quoted in Liliweri (2002: 62) defines culture as something composed of common categories of common phenomena called customs which include technology, knowledge, trust, art, moral, law, aesthetics, recreation and abilities and habits that humans get as members of society.In other words, cultural includes everything that humans get or learn as members of society.

Hawkins (2012) says that culture is a complex that includes knowledge, beliefs, art, morals, customs and other abilities and habits that humans have as part of society.Cultural is the whole way of life of society but is not only limited to it yet another part considered higher or more desirable by society. Linton, as quoted in Ihromi (2006: 18).

Therefore, cultural refers to various aspects of life including the ways of life, beliefs, and attitudes, and also the results of human activities that are unique to a particular community.

According to the Great Dictionary of the Indonesian Language, policy is a series of concepts and principles that become the outline and basis of the plan in the implementation of a job in achieving the goals or objectives.Etymologically, according to Dunn, the term policy comes from Greek, Sanskrit and Latin languages.Policy derives from the Greek language "polis" meaning "city-state" and from the Sanskrit "pur" meaning "city" from the Latin "politia" meaning state. 1 Some scientists explain various kinds of policies; Carl Friedrich, as quoted in Indiahono states that

"policy is a direction of action proposed by a person, group or government in a particular environment that provides obstacles and opportunities for policies proposed to use and overcome in order to achieve a goal, or realize a goal or a specific purpose.

$\mathrm{He}$ also said that there are several main things in the policy, i.e. goals, objectives or purposes. Meanwhile, Jones defines policies as "Permanent and repetitive behavior relates to the business within and is through the government to solve common problems. This definition means that the policy is dynamic. This will be discussed specifically in other parts, in relation to the characteristic of the policy "3

According to Abidin, policies are generally divided into 3 (three) levels: 
- General policy is a policy that becomes a guideline or instruction guide either positive or negative in nature covering the entire area or agency concerned;

- Implementation policy is a policy that sets out general policies.For the central levels the government regulations regarding the implementation of a law;

- Technical policy is the operational policies that are under the implementation policy.

\section{METHODS OF RESEARCH}

Judging from the type of data, this was qualitative descriptive researchWhat is meant by qualitative research is a study that intends to understand the phenomenon holistically experienced by research subjects and by means of descriptions in the form of words and language, in a special natural context and by utilizing various scientific methods (Moleong, 2007.

The type of research approach is descriptive.Descriptive research is a study that seeks to explain the problem solving that is now based on data.This qualitative descriptive research is intended to obtain information about the extent of community participation, character, behavior and culture in relation to the development of irrigation networks in Luwu Timur District.

In accordance with the problems studied, this study is classified into survey research.Kerlinger (2006: 660) states that survey research studies large and small populations by selecting and reviewing selected samples from the population to find relative incidence, distribution, and interrelation of psychological sociological variables.Surveys that include definitions are often called sample surveys.In line with that, Sugiono (2006: 7) states that survey research, in general, is carried out to take a generalization from in-depth observations, but the generalizations made can be more accurate if used a representative sample.

While from its nature, this research design is descriptive and correlational.Descriptive research is a study that seeks to obtain information regarding the phenomena observed today (Suharsimi, 1989).This study tries to describe data about objects or research variables that exist in the development of irrigation networks in Luwu Timur District.

Referring to the problems in the development of irrigation networks, this research is generally seen in terms of the samples to be targeted, the research is in the survey category.According to Kerlinger (2006: 660), survey research examines large and small populations by selecting and reviewing selected samples from the population to find the incidence, distribution, and relative interrelation of psychological sociological variables. This kind of survey can be said as a sample survey. This study will describe data about objects or research variables that exist for the research area, including endogenous variables or independent variables covering; Participation (X1), Character (X2), Culture (X3), Policy (X4), and Exogenous Variables or dependent variables namely Irrigation Development in Luwu Timur District (Y1).

Population is a collection of individuals with quality and characteristics that have been set (Nasir, 1988).Lin (1976) suggests that the whole group of people who have certain in accordance with the attention of researchers is called the population.Dalen and Deobold (1973) argue that population is a group of people or something that really exists and is well formulated.Therefore, the opinions of the three experts can be concluded that the population is a group of individuals who have certain qualities and characteristics that have been well defined and formulated by researchers.

The population of this research is the community members in Kalaena irrigation area in Teromu Village, Mangkutana and Tomoni Sub-districts in Luwu Timur District South Sulawesi Province and involving 10 villages that were included in the irrigation/research area.Based on the data collection plan, which is in Mangkutana and Tomoni Districts, the targeted respondents are the community in the two sub-districts predicted to have and know descriptively the questionnaire material given.

The sample as a respondent is part of the population concerned (Lin, 1976).While according to Priyatno (2008), sample is a portion of the population to be studied.Based on 
Roscoe, (1982) in Sugiyono (2006) sample sizes are as described below:If the study will do a multivariate analysis (correlation, or multiple regression for example), then the number of sample members are at least 10 times the number of variables studied.For example, the research variable is 5 (independent + dependent), then the number of sample members: $10 \times 5=50$.

Based on the provisions of the method of Structural Equation Modeling (SEM), the number of samples for 5 variables can be taken at least 200 respondents. The number of respondents for data surveys was 200 respondents, Roscoe, (1982) in Sugiyono (2006).

After data collected, It was then analyzed using a technique in accordance with the type of research.Data description used descriptive statistical analysis techniques.Data analysis used in inferential statistical methods was Analysis of Moment Structures (AMOS)

This study was analyzed using primary data collected through questionnaires using the survey method.The research questionnaire consists of questions about four variables or constructs measured by a number of indicators. Each respondent was asked to convey his perception of the indicators for these variables by choosing one number from a scale of 1 to 5.Therefore, every construct needs to be tested for validity and reliability.

Final analysis of this research is hypothesis testing. The analytical tool used to test the hypothesis is software Analaysis of Moment Structures (AMOS).

This research was conducted at Kalaena irrigation development area in Mangkutana Sub-district, Luwu Timur District, South Sulawesi Province, and focused in Mangkutana subdistrict.

As for what is meant by data sources in research is the subject from which data is obtained (Suharsimi Arikunto, 2002: 107).To get the correct data, it is necessary to determine the competent informants who are in accordance with the data needs (purposive). They are the people of Mangkutana and the surrounding society as well as all service workers of the city. This study describes how the community responds as an object, seen from the aspects of participation, character, culture, and policy related to the development of irrigation networks in Luwu Timur District.

\section{RESULTS AND DISCUSSION}

The results of regression weights are the output of statistical calculations using SEM AMOS 22,0. The results of the regression weight can be seen in table 1 .

Table 1 - The Result of Regression Weight

\begin{tabular}{|lllllll|}
\hline Variable & & & Estimate & S.E. & C.R. & P \\
\hline Peng.Jar.Irigasi & $<---$ & Participation &, 075 &, 104 &, 725 &, 469 \\
Peng.Jar.Irigasi & $<---$ & Culture &,- 070 &, 046 & -1.503 &, 133 \\
Peng.Jar.Irigasi & $<---$ & Policy &, 813 &, 089 & 9.122 & $* * *$ \\
Peng.Jar.Irigasi & $<---$ & Characteristic &, 200 &, 049 & 4,042 & $* * *$ \\
\hline
\end{tabular}

Source: Output SPSS AMOS, 22.0, 2019.

Table 1 above results in the following structural equations:

$$
Y=0.075 X 1-0.070 X 2+0.813 X 3+0.200 X 4
$$

Table 2 - The Result of Goodness-of-Fit

\begin{tabular}{|l|l|l|l|}
\hline Goodness-of-Fit Measure & Cut of Value & Result & Desc. \\
\hline chi square & Expected to be not significant & 5426.536 & Fit \\
Significance Probablity & $\leq 0.05$ & 0.000 & Significant \\
RMSEA & Between $0.05-0.08$ & 0.309 & FIT enough \\
GFI & $\geq 0.90$ & 0.460 & FIT enough \\
AGFI & $\geq 0.90$ & 0.353 & FIT enough \\
TLI & $\geq 0.95$ & 0.285 & FIT enough \\
\hline
\end{tabular}

Source: Output SPSS AMOS, 22.0, 2019. 
The table above shows the results for goodness of fit. It can be seen that the chisquare value is 66.231, the chi-square table shows a quite higher value, but a high value of degree of freedom will reduce the chi-square value so that it will be fit. Furthermore, it can be seen that the value of significance probability is 0,000 , which means that the value is significant because it is smaller than 0.005. Another criterion of goodness of fit which indicates that the model is worth investigating is the value of GFI, AGFI, and TLI where the three values are included in the criteria of good fit because it approaches a critical value or cut off where the GFI value is 0.460 , AGFI is 0.353 and TLI is 0.285 while the cut off must be greater than 0.90.Because the AGFI, GFI, and TLI values are in the fit criteria so it is feasible to be followed up.

Table 3. The Result of Goodness-of-Fit

\begin{tabular}{|cccccccc|}
\hline & & Variable & Estimate & S.E. & C.R. & P & Hypothesis \\
\hline PJI & $<---$ & Participation &, 075 &, 104 &, 725 &, 469 & Rejected \\
PJI & $<---$ & Culture &,- 070 &, 046 & -1.503 &, 133 & Rejected \\
PJI & $<---$ & Policy &, 813 &, 089 & 9.122 & $* \star *$ & Accepted \\
PJI & $<---$ & Characteristic &, 200 &, 049 & 4,042 & $* \star *$ & Accepted \\
\hline
\end{tabular}

Source: Output SPSS AMOS, 22.0, 2019.

From the table above, it can be seen that of the four variables tested for their role in irrigation network development, i.e. participation, culture, policy and character, only the policy and character of the community proved to play a role in the development of irrigation networks in Luwu Timur District.This is based on the $P$ value of the two variables smaller than $0.05 . P$ value of policy variable is $0.000(0.000<0.05)$ and $P$ value of community character is $0.000(0.000<0.05)$. Participation and community culture variable were not proven to have a role in determining the development of irrigation networks because the $P$ value of those two variables was greater than 0.05 . The $P$ value of the participation variable is $0.469(0.469>0.05)$ and the $P$ value of the culture variable is $0.133(0.133>0.05)$.

\section{CONCLUSION}

Based on the research results and discussion in the previous chapter, the conclusions of this study are as follows:

- Community participation has little role in developing irrigation networks in Luwu Timur District;

- Community characteristics play a role in the development of irrigation networks in Luwu Timur District;

- Community culture has little role in developing irrigation networks in Luwu Timur District;

- Policy plays a role in the development of irrigation networks in Luwu Timur District.

\section{REFERENCES}

1. Alo Liliweri, MS, 2003. Dasar-Dasar Komunikasi Antar Budaya. Yogyakarta: Pustaka Pelajar.

2. Arikunto, Suharsimi. 2002. Metodologi Penelitian. Jakarta: Penerbit PT. Rineka Cip.

3. Girsang, 2011. Faktor yang Mempengaruhi Partisipasi Masyarakat dalam Kegiatan Perbaikan Prasarana Jalan (Kasus: Program Nasional Pemberdayaan Masyarakat (PNPM) Mandiri Perdesaan di Desa Megamendung, Bogor). Bogor: IPB.

4. Harahap, Sofyan Safri, 2004. Analisis Krisis atas Laporan Keuangan. Jakarta: Rajawali Per.

5. Hawkins, P. (2012). Creating a Coaching Culture. New York: Bell and Bain Ltd. Diakses 20 Januari dari http://goo.gl/8Kd6Jo. 
6. Horton, Paul B., dan Chester L. Hunt. 1993. Sosiologi, Jilid 1 Edisi Keenam, (Alih Bahasa: Aminuddin Ram, Tita Sobari). Jakarta: Penerbit Erlangga.

7. Kodoatie, dan Sjarief, 2005. Pengelolaan Sumber Daya Air Terpadu. Yogyakarta: Andi.

8. Koentjaraningrat, 2000. Pengantar IImu Antropologi. Jakarta: Rineka Cipta.

9. Komaruddin, 1991. Analisis Manajemen Produksi. Jakarta: Bumi Aksara.

10. Lexy. J. Moleong, 2007. Metodologi Penelitian Kualitatif. Bandung: Remaja Rosdakarya

11. Lin, Nan. (1976). Social Movement dalam Encyclopedia of Sociology. New York: MacMillan Publishing Company.

12. M. Daud Silalahi, 2001. Hukum Lingkungan dalam Sistem Penegakan Hukum Lingkungan Indonesia. Bandung: P.T. Alumni.

13. M.Kasiram, 2006. Metodologi Penelitian: Refleksi Pengembangan, Pemahaman dan Penguasaan Materi Penelitian. Malang: UIN Maliki Press.

14. Mardiyanto Hardono, 2008. Intisari Manajemen Keuangan. Jakarta: Grasindo.

15. Masri Singarimbun \& Sofyan Effendi, 1995, Metode Penelitian Survei, Edisi. Revisi, PT. Pustaka LP3ES.

16. Merton, Robert K. 1949/1968. Manifest dan Latent Functions in R.K Merton, Social Theory and Social Structure. New York: Free Press: 73-138.

17. Minto Rahayu, 2000. Kepemimpinan Dalam Pemerintahan. Jakarta: Rajawali Pers.

18. Mudakir, Iskandar Syah. SH, MH., 2010. Pembebasan Tanah Untuk Pembangunan Kepentingan Umum, Jakarta: Jala Permata Angkasa.

19. Sugiyono, 2006. Statistika Untuk Penelitian. Bandung: CV Alfabeta. 